\title{
Crystallography in the High School Classroom.
}

\section{Williams ${ }^{1}$ \\ ${ }^{1}$ Shelter island Union Free School District, Shelter Island, NY dan.williams@shelterisland.k12.ny.us}

Scientific research is a journey, a passionate journey of exploration and discovery. The spark that ignites this journey is different for each scientist, but often is started by a teacher or professor. Protein crystallography is a difficult, long journey - from crystallization reactions through resolving a structure -and it requires remarkable passion for exploration and discovery. Training the next generation is problematic as crystallography is a difficult field to break into, and even harder to achieve success in. The SPARK program (Student Partnerships for Advanced Research and Knowledge), a collaboration of several Long Island high schools and Brookhaven National Laboratory, is a student-led crystallography program, which provides a unique opportunity to spark that passion for discovery; and it provides a realistic expectation of success, failure, and the work involved. To inspire the next generation, we have students design scientifically accurate projects, interpret results, and look beyond easy answers to think critically about their research. Everything is hands-on experimentation, in contrast to ineffectual rote memorization. Students perform every step, from crystallization and fishing to x-ray diffraction and data analysis. More importantly, student results spark scientific curiosity and an appreciation for the exciting fields of crystallography and structural biology.

Acta Cryst. (2020). A76, a40 